\title{
Empirical Investigation of the Factors Affecting Micro, Small and Medium Scale Enterprises Performance in Borno State, Nigeria
}

\author{
Fatima Alfa Tahir ${ }^{1}$, Fatimah Usman Inuwa ${ }^{2}$ \\ ${ }^{1}$ Department of Accounting, Faculty of Management Sciences, University of Maiduguri, Nigeria \\ ${ }^{2}$ Department of Business Management, Faculty of Management Sciences, University of Maiduguri, Nigeria \\ Correspondence: Fatima Alfa Tahir, Department of Accounting, Faculty of Management Sciences, University of \\ Maiduguri, Nigeria.
}

Received: January 18, 2019

Accepted: March 11, 2019

Online Published: March 13, 2019

doi:10.5539/ibr.v12n4p30

URL: https://doi.org/10.5539/ibr.v12n4p30

\begin{abstract}
Past studies have documented the relevance of strong industrial base to economic development. Although several measures have been put in place to develop the industrial sector, the performance of Micro, Small and Medium Scale Businesses (MSMEs) leaves much to be desired. This study examines socio-economic factors affecting Micro, Small and Medium Scale Enterprises Performance in Maiduguri Borno State, Nigeria. Data was generated from a survey of 84 Micro Small Medium Enterprises operators in Maiduguri and analyzed with the aid of Statistical Package for Social Sciences (SPSS) version 23. Descriptive and Inferential Statistics were used to analyze the data collected. The results from the Exploratory Factor Analysis, Correlation and Multiple Regression Analysis show that insecurity and inadequate infrastructural facilities are the most significant factors affecting MSMEs performance in Borno state. The study therefore recommends that government should provide better security and improve infrastructural facilities such as power supply in order to enhance MSMEs performance.
\end{abstract}

Keywords: infrastructure, performance, insecurity, training, government policies, MSMEs

\section{Introduction}

Micro, Small and Medium Scale Enterprises (MSMEs) make up about $95 \%$ of the manufacturing industries in Nigeria (Ogunleye, 2004). Yet, unlike the developed economies, MSMEs contribute very little in terms of output, exports and employment, in Nigeria. This may perhaps be due to differences in business environments, social, economic, cultural and legal factors that influence the operations of MSMEs. There are several challenges arising from these factors such as increased risk, cost of business, and difficulty in taking decisions and delay in business transactions for Nigerian business entrepreneurs (KPMG, 2012). In addition, indices from the Doing Business Index (DB) shows that MSMEs in Nigeria encounter several challenges in undertaking commercial activities. This implies that there are peculiarities in socio-cultural factors in the country that inhibit transfer of management practices from other countries. Furthermore, Majority of Entrepreneurs in Africa are MSME owners who face challenges in sustaining their trades and imbibing new technologies for enhanced performance and growth (OCED, 2009). Other reports suggest that African entrepreneurs focus mainly on local market without exploring other avenues for long- term advancement and expansion (Beyene, 2002).

The number of MSMEs in Nigeria has been on the rise for several reasons. Firstly, MSMEs require less capital, manpower, technical know-how and managerial skill to start. Secondly, they create employment opportunities to their immediate environments by utilizing local material and human resources thereby promoting economic growth and industrialization. Several studies have also documented the relevance of MSMEs in various developed and emerging economies. For instance, Fan (2003) reported that MSMEs account for 55\% of the gross domestic product of high income countries and $60 \%$ of that of low income countries. Ariyo (2006) noted that MSMEs were also engaging more than $65 \%$ of the workforce in high income countries and more than $70 \%$ workforce in low income countries. Rajesh, Suresh and Deshmukh (2008) assert that MSMEs are the pillar for sustainable economic growth in all countries. Micro, Small and Medium Scale businesses play a significant role in the industrial development of any nation. Over the years, Nigeria has experienced a rise in the level of unemployment which has had an adverse effect on the economic development of the nation. However, with the rapid growth of MSMEs and diversification of businesses, more youths have been engaged and acquired skills for 
entrepreneurship. The General Statistics Office (2007) reports that MSMEs are integral to Nigeria's economic growth because they make up $97 \%$ of industrial companies. The establishment and growth of MSMEs has also been linked to reduction in poverty and economic dependency. Lalkaka (1997) stated that MSMEs are regarded as vital for economic growth, source of employment and a means to poverty eradication. MSMEs also help to ensure efficient allocation of human and material resources in the country by reducing wastages and underutilization of local resources. This has in turn will lead to economic development of the nation.

Despite these assertions, Agwu and Emeti (2014) note that MSMEs performance has generated a lot of scholarly attention because they have not yielded the expected benefits in recent years. In addition to other challenges encountered in other states, Tahir and Usman (2018) have reported that entrepreneurs in Borno state particularly face enormous challenges that have been compounded by the Boko Haram insurgency and insecurities abound. It is therefore very important to examine the peculiar challenges hampering performance of MSMEs in Borno state, Nigeria. In this regard, the study seeks the following objectives:

i. $\quad$ Examine the effect of Infrastructural facilities on the performance of MSMEs in Borno state, Nigeria

ii. Assess the influence of insecurity on the performance of MSMEs in Borno state, Nigeria

iii. Examine the impact of government policies on MSMEs performance in Borno state, Nigeria

iv. Investigate the effect of training on the performance of MSMEs in Borno state, Nigeria

Borno state is strategically located in the Northeast of Nigeria bordering Chad, Niger and the republic of Cameroon making it best fit for cross border trade among these three countries. MSMEs in Borno state are better placed to explore these trade advantages and boost the economy of the state and Nigeria in general. Understanding these challenges will not only enhance MSMEs performance, it will also boost economic activities and provide gainful employment to the youths. The study results are also expected to assist in developing viable suggestions and alternatives on how to address the factors affecting MSMEs performance in Nigeria in general, and Borno state in particular. The remainder of this paper is organized into five sections; Literature Review, Research Framework, Methods, Results and Discussions and Conclusions.

\section{Literature Review}

\subsection{Micro, Small and Medium Scale Enterprises}

According to National Policy, Micro, Small and Medium Enterprises (MSMEs) can be categorized according to size, sector, organization, technology and location. In fact, the definition of MSMEs differ across countries, economies, agencies and sectors even though all encompass three distinct groups; micro, small and medium scale businesses (Lucky \& Olusegun, 2012). For instance, while Britain, the United States and some European countries define small-scale enterprises in relation to sales and number of employees, MSMEs in Nigeria are defined in relation to capital employed, turnover and number of employees (Gbandi \& Amissah, 2014). Oboniye (2013) defines MSME as any business that employs less than 50 persons and has capital less than $\$ 500,000$. According to the Central Bank of Nigeria (CBN, 2004), MSMEs refer to businesses having total cost plus working capital ranging from $\$ 1,000,000$ to $10,000,000$. The Nigerian Industrial Development Bank (NIDB) describes MSMEs as enterprises having capital and project cost of $750,000.00$. Conversely, The National Economy Reconstruction Fund (NERFUND) define MSMEs as companies having fixed assets and investment costs of up to $\$ 10,000,000$ or less. This study defines MSMEs in line with NERFUND as any enterprise that has capital investments of up to $\$ 10,000,000$ or less.

\subsection{Micro Small and Medium Enterprises Performance}

Performance can be defined in various contexts depending whether objective (quantitative/financial) or subjective (qualitative/non-financial) measures are used. Financial performance measures organizational effectiveness using yardsticks of profitability such as Return on Assets (ROA), Return on Equity (ROE), Net Profit or Gross Profit (Parker, 2000). Non-financial performance measures relate to qualitative effectiveness such as growth, expansion, efficient service delivery, product quality, survival and competitiveness (Dobbs \& Hamilton, 2007). According to Sandberg, Vinberg and Pan (2002) MSMEs performance refers to their ability to generate wealth and jobs through business start-ups, growth, survival and expansion. This is because overall performance of the organization is dependent on good management (Gibcus \& Kemp, 2003). In addition, measuring MSMEs performance can help identify their strengths and weaknesses in the light of existing results (Eniola \& Entebang, 2015). Past studies on MSMEs have used various measures of performance such as financial, non- financial or a combination of both. However, this study will employ non-financial (qualitative) measures because majority of MSMEs owners do not disclose financial information. This also follows Ladzani and Seeletse, (2012) who noted that MSMEs financial information is generally sensitive and not disclosed by owners. As such, this study employed statements related to other qualitative aspects of performance to elicit information from MSMEs owners and managers. 


\subsection{Infrastructural Facilities and MSMEs Performance}

Infrastructure refers to the basic facilities and equipments required for the smooth running of the general public. According to Srinivasu and Rao (2013) infrastructure refers to the amenities through which products and services are provided to the people. These basic amenities include portable water, power supply, roads, railways, ports, telecommunications, hospitals and schools among others (Fulmer, 2009). Past studies indicate that infrastructure influences MSMEs performance in various respects. For example, Scott, Darko, Lemma, and Rud (2014) report that the efficiency of manufacturing MSMEs in Bangladesh, Nepal, Nigeria, Pakistan, Tazania and Uganda has been greatly hampered by irregular power supply. Nkechi Ikechukwu and Okechukwu (2012) note that adequate infrastructural facilities increase MSMEs performance. This is because the availability of these facilities create a favorable environment for MSMEs to excel thereby boosting economic growth (Beyene, 2002). Good infrastructure is vital if MSMEs are to break even and be profitable. Ebert and Memillen (1999) posit that firms are more productive when public infrastructure is adequately available. In addition, the growth and expansion in telecommunication industry has also boosted MSMEs linkages to various clients and support agencies resulting in improved performance. Nkechi et al (2012) report that MSMEs benefitting from agency support and soft loans are more likely to grow and survive than others not having such privileges. Yet, a few studies report infrastructure has a negative effect. For example, Akinbogun (2008) discovered that infrastructural facilities were inadequate and failed to support growth of viable MSMEs in the ceramic industry in Nigeria. Furthermore, the results from Kinyua (2014) show existing infrastructural facilities do not enhance the performance of SMEs. In line with these discussions, this study formulates hypothesis one:

\section{H1: Infrastructure has a significant and positive effect on MSMEs performance in Borno State}

\subsection{Insecurity and MSMEs Performance}

Insecurity generally refers to a lack of protection or being open to threats or danger to lives and properties. These threats result from kidnapping, terrorism, human trafficking, armed robbery, ritual killings, communal clashes, and farmer-herder conflict among others (Abbas \& Mohammed, 2016). Insecurity has been on the rise in several parts of Nigeria putting pressure on the government and security agencies to safeguard the lives and properties of Nigerians (Adegbami, 2013). This is because insecurity discourages investment and results in a huge drawback and blockade to business investment. Past studies indicate that insecurity exerts an enormous influence on the business environment in general and MSMEs in particular. For instance, Okpaga, Ugwu, and Eme, (2012) reported that there has been a waning of business activities from 2009 to 2012 due to the actions of Boko Haram insurgents in the North east. In addition, Chukurah, Eme and Ogbeje (2015) noted that north-east has suffered more than one hundred and fifteen (115) attacks by terrorist insurgents making the environment dangerous and pushing entrepreneurs to move to safer environments. Nnamdi, Sebastine, Junior and Anyanwu (2015) noted that entrepreneurial relocation has crippled the activities of MSMEs in the north east and business activities in general. Even the businesses that remained in operation have suffered several hardships, underdevelopment, backwardness, loss and ultimately, poverty (Ali, Musa \& Fada, 2016). These unfortunate incidents have impaired growth and economic development of not only the region but has also portrayed Nigeria as an unsafe environment for foreign investments (Nafiu, Okpanachi \& Nurudeen, 2014). The Global Peace Initiative-also reported a significant decline in peace as Nigeria ranked 149th out of 163 countries in the 2017 Global Peace Ranking, making Nigeria the least peaceful country in West Africa (GPI, 2017). Furthermore, the Trading Economies (TE, 2018) shows Nigeria suffered a decline in foreign direct investment in 2018 ( $\$ 808.56$ million) compared to 2012 ( $\$ 3,084.9$ billion). This is because the country is perceived as volatile and very risky. The results of these insecurities cast doubt on the safety of investment thereby discouraging indigenous businesses in general and foreign direct investment in Nigeria in particular. In line with these arguments and assertions, this paper postulates:

H2: Insecurity has a significant negative effect on MSMEs performance in Borno state

\subsection{Government Policies and MSMEs Performance}

Government policies are regulatory pronouncements or instruments that regimes employ to guide the conduct of businesses. The state of the economy however, guides the extent and direction of government policies. For instance, Sathe (2006) asserts that government regulations can deter or enhance small businesses. When the goal is enhancement, policies aim to promote development, healthy competition, growth and quality products and services. Similarly, government can also implement restrictive policies such as fiscal policies that aim to control business operations or autonomy (Eniola \& Entebang, 2015). Literature on MSMEs have suggested that government policies has a major effect on the MSMEs performance. For instance, Okpara (2011) reported that MSMEs fail in Nigeria due to several factors such as inadequate financial support, poor administration, unfavorable tax policies and lack of incentives. Some studies provide evidence that these policies affect MSMEs 
performance. For instance, Agwu and Emeti (2014) showed that multiple taxes are a huge constraint to maximizing profits that could be ploughed back into the business for expansion and growth. Eniola and Entebang (2014) note that tax waiver incentives also encourage small businesses to grow and expand. In fact, Okpara (2011) found that policies promoting MSME access to capital and equipment, loans as well as exemptions have reduced MSMEs costs, enhanced profits and growth. In line with these discussions, this study postulates hypothesis three:

H3: Government policies have significant effect on MSMEs performance in Borno state

\subsection{Training and MSMEs Performance}

Training refers to the attainment of expertise, knowledge and capabilities acquired through teaching of vocational or practical knowledge aimed at achieving a particular purpose (Abdullahi, et al. 2015). Training improves human intellectual ability, efficiency, skill, competence and performance. According to the Industrial Training Fund (ITF, 2006) training is a process by which knowledge, talents and skills of employees are improved. Prior studies show that entrepreneurial training is vital to the growth and survival of MSMEs. According to Oforegbunam and Okorafor (2010), training increases employee productivity, efficiency, competence and attainment of organizational objectives. Bruderl, Preisendorfer and Ziegler (1992) show that entrepreneurs that receive training are more productive and perform better than those who did not. In addition, Betcherman, Leckie and McMullen (1997) showed that small businesses that had well-structured training curricula achieved better results in terms of revenues, profits, product quality and service delivery. Beaver and Hutchngs (2005) reported that training promotes learning and enhances employee competence leading to better performance. These studies found training significantly affected entrepreneurial performance. In line with these discussions, this study proposes hypothesis four:

H4: Training has a significant and positive effect on MSMEs performance in Borno state

\section{Research Framework}

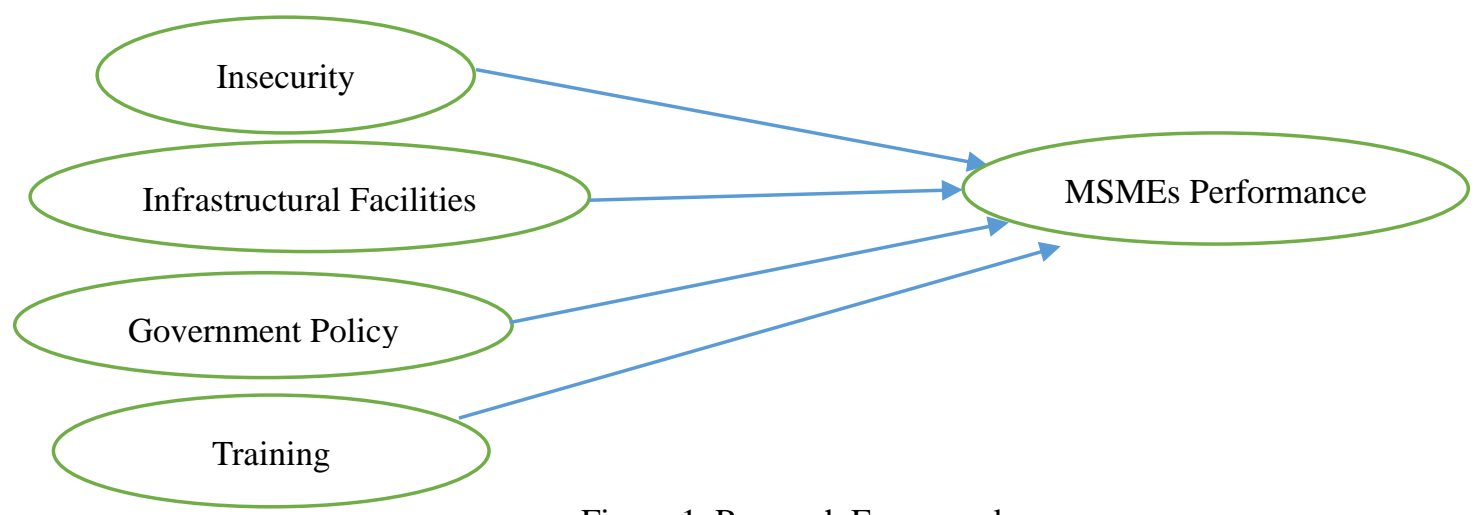

Figure 1. Research Framework

The research framework on figure 1 shows four factors; Insecurity, Infrastructural Facilities, Government Policy and Training are hypothesized to affect MSMEs performance in Maiduguri, Borno state. Insecurity is captured in terms of extent of destruction to properties, disruption of business, displacement and restriction of movement. Infrastructural facilities are assessed in terms of adequacy of communication and road network, effectiveness of transportation systems, stability of power supply and ICT globalization level. Government policy is measured in terms of tax policies, regulations, subsidies, and the influence of local rates, fares and charges. Training covers effects of free capacity training, extent of reliance on vocational training, enhancement of skills and increase of output. Together, these factors are posited to affect MSMEs performance in Borno state, Nigeria. Therefore, these factors are postulated as the principal factors affecting MSMEs performance in Borno state, Nigeria.

\section{Method}

The study employed the survey method to obtain data from operators of MSMEs about the factors affecting MSMEs performance. The instrument was tested on two MSME owners to ascertain whether the items were clear and reliable. The instruments were then administered to MSME respondents operating in Maiduguri Metropolis. From the records obtained from the Council, there are 2416 registered business in the 15 wards in Maiduguri. The study used simple random sampling technique to select 350 MSME owners in Maiduguri metropolis.

\section{Results and Discussions}

The data collected was analyzed using descriptive and inferential tests. Instruments were collected after 10 days of administration. A total of 110 instruments were retrieved from MSME operators representing a response rate of 
$33.2 \%$. Of the 110 instruments, 26 were discarded because they had significant number of missing values. This resulted in 84 valid instruments which informs the analysis. Table 1 shows respondents' demographic profile.

Table 1. Respondents' Demographic Profile

\begin{tabular}{|c|c|c|}
\hline Item & Frequency & Percentage $\%$ \\
\hline \multicolumn{3}{|l|}{ Gender } \\
\hline Male & 58 & 69 \\
\hline Female & 26 & 31 \\
\hline \multicolumn{3}{|l|}{ Age Category } \\
\hline $18-25$ & 12 & 14.3 \\
\hline $26-35$ & 39 & 46.4 \\
\hline $36-45$ & 25 & 29.8 \\
\hline $46-55$ & 8 & 9.5 \\
\hline \multicolumn{3}{|l|}{ Business Type } \\
\hline Mobile accessories business & 21 & 25 \\
\hline Carpentry & 17 & 20.2 \\
\hline Restaurant business & 15 & 17.9 \\
\hline Tailoring & 11 & 13.1 \\
\hline Retail store business & 14 & 16.7 \\
\hline Stationary business & 6 & 7.1 \\
\hline \multicolumn{3}{|l|}{ Years of Business } \\
\hline 0 -2years & 33 & 39.3 \\
\hline 3-6years & 25 & 29.8 \\
\hline 7-10years & 15 & 17.9 \\
\hline 11-13years & 5 & 6 \\
\hline 21 and above & 38 & 31.1 \\
\hline 14-17years & 4 & 4.8 \\
\hline 18-20years & 2 & 2.4 \\
\hline \multicolumn{3}{|l|}{ Average Profit Per Annum } \\
\hline N100,000-N500,000 & 34 & 40.5 \\
\hline N501,000-N1,000,000 & 25 & 29.8 \\
\hline $\mathrm{N} 1,001,000-\mathrm{N} 1,500,000$ & 9 & 10.7 \\
\hline $\mathrm{N} 1,501,000-\mathrm{N} 2,000,000$ & 5 & 6 \\
\hline $\mathrm{N} 2,001,000-\mathrm{N} 2,500,000$ & 4 & 4.8 \\
\hline $\mathrm{N} 2,501,000-\mathrm{N} 3,000,000$ & 3 & 3.6 \\
\hline $\mathrm{N} 3,001,000-\mathrm{N} 3,500,000$ & 1 & 1.2 \\
\hline $\mathrm{N} 3,501,000-\mathrm{N} 4,000,000$ & 2 & 2.4 \\
\hline Above N4,000,000 & 1 & 1.2 \\
\hline
\end{tabular}

Of the 84 respondents, $69 \%$ were male and $31 \%$ female while $86 \%$ were above 25 years. The entrepreneurs comprised of mobile accessories vendors (25\%), carpenters (20\%), restaurant owners (18\%), tailors (13\%), retail store owners (17\%) and stationery business owners (7\%). Majority of the MSME owners (69\%) have been in operations for 6 years or below while only $7 \%$ of the business have been in operation for 14 years and above. About $80 \%$ of the businesses made average annual profit of NI, 500,000 or below.

\subsection{Reliability Test and Exploratory Factor Analysis}

The items in each variable were assessed to establish their internal consistency and reliability. The Cronbach alpha coefficient shows all variables have exceeded the minimum benchmark of 0.7 (Sekaran \& Bougie, 2010). Hence all item measures are considered reliable and consistent in measurement. Exploratory factor analysis (EFA) was also undertaken to establish preliminary relationships in order to identify the principal components that can represent the variables. The Bartlett's test is significant (.000) and the Kaiser Myer Olkin (KMO) measure is 0.735 which exceeds Hair et al (2010) minimum acceptable benchmark (0.70). The anti-image correlation for each factor for each item met the 0.50 benchmark indicating that factors are reasonably associated with each other. Next, communality values for each item exceeds 0.50 benchmark (Hair et al., 2010) ranging from 0.580 to 0.900 . The total variance explained by the variables is $72 \%$ (Hair et al., 2010). The rotated factor matrix shows all factor loadings are significant (>.50) and load on only one construct.

\subsection{Correlation Results}

Pearson product-moment correlation was run on the five variables of the study in order to examine the correlation between the variables (infrastructure, insecurity, government policy, power supply and SME performance). 
Table 2. Pearson Correlation

\begin{tabular}{|c|c|c|c|c|c|c|}
\hline & & Minfra & MInsec & Mtrain & MGovPol & MSmeperf \\
\hline Minfra & $\begin{array}{l}\text { Pearson Correlation } \\
\text { Sig. (2-tailed) }\end{array}$ & 1 & & & & \\
\hline MInsec & $\begin{array}{l}\text { Pearson Correlation } \\
\text { Sig. (2-tailed) }\end{array}$ & $\begin{array}{l}.056 \\
.615\end{array}$ & 1 & & & \\
\hline Mtrain & $\begin{array}{l}\text { Pearson Correlation } \\
\text { Sig. (2-tailed) }\end{array}$ & $\begin{array}{l}. \mathbf{3 3 4}^{* *} \\
.002\end{array}$ & $\begin{array}{l}.045 \\
.688\end{array}$ & 1 & & \\
\hline MGovPol & $\begin{array}{l}\text { Pearson Correlation } \\
\text { Sig. (2-tailed) }\end{array}$ & $\begin{array}{l}.290^{* *} \\
.007\end{array}$ & $\begin{array}{l}-.098 \\
.377\end{array}$ & $\begin{array}{l}. \mathbf{3 6 3}^{* *} \\
.001\end{array}$ & 1 & \\
\hline MSmeperf & $\begin{array}{l}\text { Pearson Correlation } \\
\text { Sig. (2-tailed) }\end{array}$ & $\begin{array}{l}.405^{* * *} \\
.000\end{array}$ & $\begin{array}{l}-.311^{* *} \\
.004\end{array}$ & $\begin{array}{l}.390^{* * *} \\
.000\end{array}$ & $\begin{array}{l}.399^{* *} \\
.000\end{array}$ & 1 \\
\hline
\end{tabular}

**. Correlation is significant at the 0.01 level (2-tailed).

Table 2 shows infrastructure is positively correlated with training, government policy and MSME performance $(.334, .290 \& .405)$ all significant at $1 \%(\mathrm{P}=.002, .007 \& .000)$. In addition, training and government policy are positively correlated to MSMEs. Performance $(.363, .390 \& .399)$ at $1 \%(\mathrm{P}=.001, .000 \& .000)$. However, MSMEs performance is significantly negatively correlated to insecurity (.-.311) at $1 \%(\mathrm{P}=.004)$.

\subsection{Multiple Regression Results}

Multiple regression was run using the variables in order to examine the extent of the relationship among the variables and ascertain if the variables can predict MSMEs performance. The results on table 3 show an adjusted R square of $35.5 \%$ implying that the variables (infrastructure, insecurity, government policy and training) predict variation in the dependent variable (MSMEs performance) by $35.5 \%$ and $64.5 \%$ variation is explained by other variables outside this study's focus. The F statistic is positive (12.439) and significant at $1 \%(\mathrm{P}=.000)$ indicating that the model is fit and reliable.

Table 3. Regression Model Summary ${ }^{\mathrm{b}}$

\begin{tabular}{|c|c|c|c|c|c|c|c|}
\hline \multirow{3}{*}{$\begin{array}{l}\text { Model } \\
1\end{array}$} & \multicolumn{3}{|c|}{$\mathrm{R}$} & \multirow{2}{*}{\multicolumn{2}{|c|}{ Std. Err }} & \multirow{3}{*}{$\frac{\text { Sig. }}{000^{b}}$} & \multirow{3}{*}{$\begin{array}{l}\text { Durbin-Watson } \\
2.629\end{array}$} \\
\hline & $\mathrm{R}$ & Square & Adjusted R Square & & & & \\
\hline & $.622^{\mathrm{a}}$ & .386 & .355 & .62952 & 12.439 & & \\
\hline
\end{tabular}

a. Predictors: (Constant), MGovPol, MInsec, Minfra, Mtrain

b. Dependent Variable: MSmeperf

Table 4. Regression Coefficients ${ }^{\mathrm{a}}$

\begin{tabular}{|c|c|c|c|c|c|c|c|c|}
\hline \multirow[b]{2}{*}{ Model } & & \multicolumn{2}{|c|}{$\begin{array}{l}\text { Unstandardized } \\
\text { Coefficients }\end{array}$} & \multicolumn{3}{|c|}{$\begin{array}{l}\text { Standardized } \\
\text { Coefficients }\end{array}$} & \multicolumn{2}{|c|}{ Collinearity Statistics } \\
\hline & & $\mathrm{B}$ & Std. Error & Beta & $\mathrm{t}$ & Sig. & Tolerance & VIF \\
\hline & (Constant) & 2.094 & .439 & & 4.775 & .000 & & \\
\hline & MInsec & -.415 & .116 & -.318 & -3.571 & .001 & .979 & 1.022 \\
\hline & Mtrain & .270 & .112 & .237 & 2.417 & .018 & .808 & 1.238 \\
\hline & Minfra & .426 & .142 & .285 & 2.989 & .004 & .852 & 1.174 \\
\hline 1 & MGovPol & .285 & .139 & .199 & 2.047 & .044 & .821 & 1.217 \\
\hline
\end{tabular}

a. Dependent Variable: MSmeperf

The regression coefficients are presented on table 4. The result on infrastructural facilities is significant at $1 \%$ $(\mathrm{t}=2.989 ; \mathrm{P}=.004)$. This shows that infrastructure facilities significantly predict MSMEs performance. This finding concurs with Abdullahi et al. (2015) results that shows infrastructural facilities enhance small businesses' performance. Therefore, hypothesis one (H1) which states that Infrastructure has a significant positive effect on MSMEs performance in Borno state is supported. However, insecurity has a significant negative effect $(\mathrm{t}=-3.571$; $\mathrm{P}=.001$ ) on MSMEs performance. This implies that insecurity is a significant predictor of MSMEs performance. In other words, a rise in insecurity results in a negative influence on MSMEs performance in Borno State. This finding is in line with Abbas and Mohammed (2016) who found that insecurity and insurgency has affected businesses in north eastern Nigeria. Hence, hypothesis two (H2) which state that Insecurity has a significant negative effect on MSMEs performance in Borno State is supported. Further, training significantly and positively affects MSMEs performance ( $\mathrm{t}=2.417 ; \mathrm{P}=.018$ ). This finding suggests increasing MSMEs training will result in an equivalent rise in performance of MSMEs. This finding is in line with Eniola \& Entebang (2015) results that entrepreushirial training influences small businesses performance. 
Therefore, hypotheses three (H3) is supported. Finally, government policy significantly and positively influences MSMEs performance $(\mathrm{t}=2.047 ; \mathrm{P}=.044)$. This finding suggests that an increase in government policies and incentives results in a corresponding increase in performance of MSMEs. Therefore, hypotheses four (H4) is supported. In assessing the robustness of the model, the tolerance value is $<1$ and Variance Inflation Factor $<10$ and so are reasonably within limits and rules out the existence of Multicollinearity in the model. Similarly, the Durbin-Watson statistic of 2.62 is $<4$ and indicates no auto correlation. Overall, the results show that the model is fit and robust.

\section{Discussions and Conclusions}

This study contributes to the studies on MSMEs in numerous ways. First, it extends Abdullahi et al. (2015) and Tahir and Usman (2018) study by including several other factors such as government policies and Insecurity in an empirical study. This is also important because it provides greater insight on challenges peculiar to MSMEs in Borno state so that government can focus on eradicating these challenges and pave way for better performance. Second, the correlation and regression results show infrastructure and MSMEs performance are positively and significantly related. This is consistent with prior studies such as Amwele (2013) and Abdullahi et al. (2015). This implies that government should upgrade existing infrastructure especially power supply and good road network so that MSMEs can enhance their productivity. Third, Government policies and training are also significantly and positively associated with MSMEs performance. The regression results also show that government policies and training are significant predictors of MSMEs performance. This is also consistent with prior studies such as Eniola \& Entebang (2015) and Abdullahi et al. (2015). This means that government should periodically implement training schemes and skill acquisition programmes for greater enlightenment and competence of MSME owners and managers. Similarly, favourable policies such as tax waivers can also help in encouraging and promoting MSME performance, growth and productivity. Fourthly, Insecurity is also significantly but negatively correlated with MSMEs performance. The regression results also show that insecurity is significant and negatively affects MSMEs performance. This finding is also consistent with prior studies such as Abbas and Mohammed (2016). In fact, Insecurity has the highest impact on MSME performance compared to the other factors. This means that government must ensure that they eradicate all forms of insecurity before any meaningful performance from MSMEs can be achieved. In sum, the results show that all the factors influence MSMEs performance even though insecurity has the most significant impact in Borno state. Thus, the paper concludes that government should tailor its policies to enhance MSMEs performance by providing adequate infrastructure, training and curb the activities of insurgents so that MSMEs can grow and prosper in building the economy of the state. Despite its contributions to knowledge, the study has some limitations. The results were based on data from a survey which is prone to several shortcomings. In addition, the study did not examine differences in perception between MSME owners and managers nor test for non- response bias among the respondents sampled. Furthermore, perceptions of Nigerian MSME owners may differ from MSME owners in other countries because contextual factors and country peculiarities. Regardless of these limitations, the findings have important ramifications for MSME owners and government. The study limitations provide areas for further research on factors influencing MSME performance. In addition, the factors studied accounted for $36 \%$ of the variance explaining MSME performance. Hence other variables outside those considered here need to be investigated.

\section{References}

Abbas, S. S., \& Mohammed, M. S. (2016). Effect of Insurgency on Operations of Small and Medium Business Enterprises: A Study on Impact Assessment in Nigeria, Indian Journal of Applied Research, 6(9), 487-490.

Abdullahi, M. S., Ghazali, P. L., Awang, Z., Mohd Tahir, I., Ali, M., \& Salim, N. A. (2015). The Effect of Finance, Infrastructure and Training on the Performance of Small and Medium Scale Enterprises (SMEs) in Nigeria. International Journal of Business and Technopreneurship, 5(3), 421-452.

Adegbami, A. (2013). Insecurity: A threat to human existence and economic development in Nigeria. Public Policy and Administrative Research, 3(6), 8-13.

Agwu, M. O., \& Emeti, C. I. (2014). Issues, challenges and prospects of small and medium scale enterprises (SMEs) in Port-Harcourt city. European Journal of Sustainable Development, 3(1), 101-114. https://doi.org/10.14207/ejsd.2014.v3n1p101

Akinbogun, T. L. (2008). The impact of Nigerian business environment on the survival of small-scale ceramic industries: Case study, South-Western Nigeria. Journal of Asian and African studies, 43(6), 663-679. https://doi.org/10.1177/0021909608096659 
Ali, Y. M., Musa, B. M., \& Fada, K. A. Implications of Boko Haram Insurgency on Small and Medium Enterprises in Borno State, Nigeria: A Review. Sahel Analyst, 96-108.

Amwele, H. N. (2013). An empirical investigation into the factors affecting the performance of SMEs in the retail sector in Windhoek, Namibia (Doctoral dissertation).

Ariyo, D. (2006). Small firms are the backbone of the Nigerian economy. Retrieved September 14. 2006. www.afbis.com/analysis/small.htm

Beaver, G., \& Hutchings, K. (2005). Training and developing an age diverse workforce in SMEs: The need for a strategic approach. Education+ Training, 47(8/9), 592-604. https://doi.org/10.1108/00400910510633134

Betcherman, G., Leckie, N., \& McMullen, K. E. (1997). Developing skills in the Canadian workplace: The results of the Ekos Workplace Training Survey. Ottawa: Canadian Policy Research Networks.

Beyene, A. (2002). Enhancing the competitiveness and productivity of small and medium scale enterprises (SMEs) in Africa: An analysis of differential roles of national governments through improved support services. Africa development, 27(3), 130-156.

Brüderl, J., Preisendörfer, P., \& Ziegler, R. (1992). Survival chances of newly founded business organizations. American sociological review, 227-242. https://doi.org/10.2307/2096207

Chukwurah, D. C., Eme, O., \& Ogbeje, E. N. (2015). Implication of Boko Haram terrorism on northern Nigeria. Mediterranean Journal of Social Sciences, 6(3), 371-379. https://doi.org/10.5901/mjss.2015.v6n3p371

Dobbs, M., \& Hamilton, R. T. (2007). Small business growth: recent evidence and new directions. International Journal of Entrepreneurial Behavior \& Research, 13(5), 296-322. https://doi.org/10.1108/13552550710780885

Ebert, R., \& McMillen, D. (1999). Agglomeration Economies and Urban Public Infrastructure in Handbook of Regional and Urban Economics Vol. II edited by ES Mills and P. Chelshire.

Eniola, A. A., \& Entebang, H. (2015). SME firm performance-financial innovation and challenges. Procedia-Social and Behavioral Sciences, 195, 334-342. https://doi.org/10.1016/j.sbspro.2015.06.361

Fan, Q. (2003, September). Importance of SMEs and the role of public support in promoting SME development. In Creating a conducive Legal and Regulatory Framework for Small and Medium Enterprise Development in Russia," A Policy Dialogue Workshop, St Petersburg, Russia.

Fulmer, J. (2009). What in the world is Infrastructure? PEI Infrastructure investor, 1(4), 30-32.

Gbandi, E. C., \& Amissah, G. (2014). Financing options for small and medium enterprises (SMEs) in Nigeria. European Scientific Journal, ESJ, 10(1), 327-340.

Gibcus, P., \& Kemp, R. G. M. (2003). Strategy and small firm performance. EIM Business \& Policy Research, $1-75$.

Hair, J. F., W. C. Black, B. J. Babin, et al., (2010). Multivariate Data Analysis: A Global Perspective. Upper Saddle River, New Jersey, Pearson Prentice Hall.

Kinyua, A. N. (2014). Factors affecting the performance of Small and Medium Enterprises in the Jua kali sector in Nakuru Town, Kenya. Journal of Business and Management, 6(1), 5-10.

Lalkaka, R. (1997). Lessons from international experience for the promotion of business incubation systems in emerging economies: UNIDO, Small and Medium Industries Branch.

Lucky, E. O. I., Olusegun, A. I., \& Bakar, M. S. (2012). Determinants of Business Success: Trust or Business Policy? Researchers World, 3(3), 37-42

Nafiu, A. T., Okpanachi, E. V., \& Nurudeen, Z. Y. (2014). An Examination of the Impact of Terrorism on Small and Medium Scale Enterprises' Mortality Rates and Standard of Living in the Northern Region of Nigeria. International Journal of Innovation and Applied Studies, 7(4), 1400-1407.

Nkechi, A., Emeh Ikechukwu, E. J., \& Okechukwu, U. F. (2012). Entrepreneurship development and employment generation in Nigeria: Problems and prospects. Universal Journal of Education and General Studies, 1(4), 88-102.

Nnamdi, A. C., Sebastine, I. A., Junior, O. E., \& Anyanwu, K. (2015). BokoHaram Crisis and Implications for 
Development in the Northern Nigeria, International Journal of Economics, Commerce, and Management, 3(4), 1-12.

Oboniye, J. A. (2013). Small scale industries and rural development in Edo State, Nigeria. Journal of Educational and Social Research, 3(9), 25-33.

Oforegbunam, E. T., \& Okorafor, G. T. (2010). Effects of human capital development on the performance of small \& medium scaled enterprises in the Southeastern Region of Nigeria. Journal of Sustainable Development in Africa, 12(8), 49-58.

Ogunleye, G. (2004). SMEs as Foundation for Rapid Economic Development in Nigeria. SMIEIS Newsletter, 33-56.

Okpaga, A., Ugwu, S. C., \& Eme, O. I. (2012). Activities of Boko Haram and insecurity question in Nigeria. Oman Chapter of Arabian Journal of Business and Management Review,34(965), 1-23. https://doi.org/10.12816/0002163

Okpara, J. O. (2011). Factors constraining the growth and survival of SMEs in Nigeria: Implications for poverty alleviation. Management Research Review, 34(2), 156-171. https://doi.org/10.1108/01409171111102786

Parker, C. (2000). Performance measurement. Work Study, 49(2), 63-66. https://doi.org/10.1108/00438020010311197

Rajesh, K. S., Suresh, K. G., \& Deshmukh, S. G. (2008). Competency and performance analysis of Indian SMEs and large organizations. Competitiveness Review: An International Business Journal, 18(4), 308-321. https://doi.org/10.1108/10595420810920798

Sandberg, K., Vinberg, S., \& Pan, Y. (2002). An exploratory study of women in microenterprise: Owner perceptions of economic policy in a rural municipality: Gender-related differences. Paper presented at the CD-proceedings of 12th Nordic Conference on Small Business Research, 1-14.

Sathe, V. (2006). Corporate entrepreneurship: Top managers and new business creation. Cambridge: Cambridge university press.

Scott, A., Darko, E., Lemma, A., \& Rud, J. P. (2014). How does electricity insecurity affect businesses in low and middle income countries. Shaping Policy for Development, 1-80.

Seeletse, S. M., \& Ladzani, M. W. (2012). Social responsibility in the rural businesses of the North-West Province of South Africa: Coerced or business-driven? African Journal of Business Management, 6(46), 11457-11471. https://doi.org/10.5897/AJBM12.685

Sekaran, U., \& Bougie, R. (2010). Research methods for business: A skill building approach (5th ed., United Kindom: John Wiley \& Sons Ltd.

Srinivasu, B., \& Rao, P. S. (2013). Infrastructure development and economic growth: Prospects and perspective. Journal of Business Management and Social Sciences Research, 2(1), 81-91.

Usman, F. I., \& Tahir, F. A. (2018). Factors influencing performance of micro, small and medium scale enterprises in Borno State, Nigeria: An exploratory study. Australian Journal of Business and Management Research, 5(9), 17-24. 


\section{Appendix A}

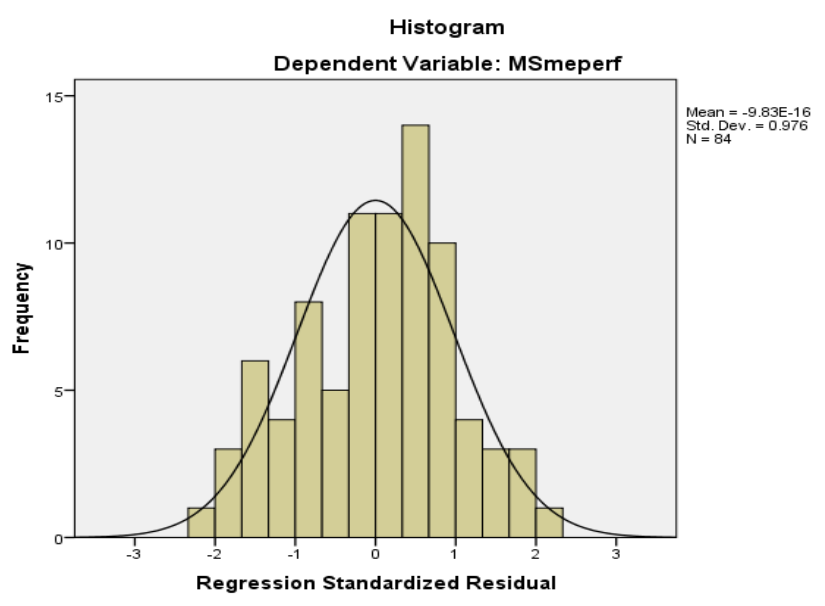

\section{Appendix B}

Normal P-P Plot of Regression Standardized Residual

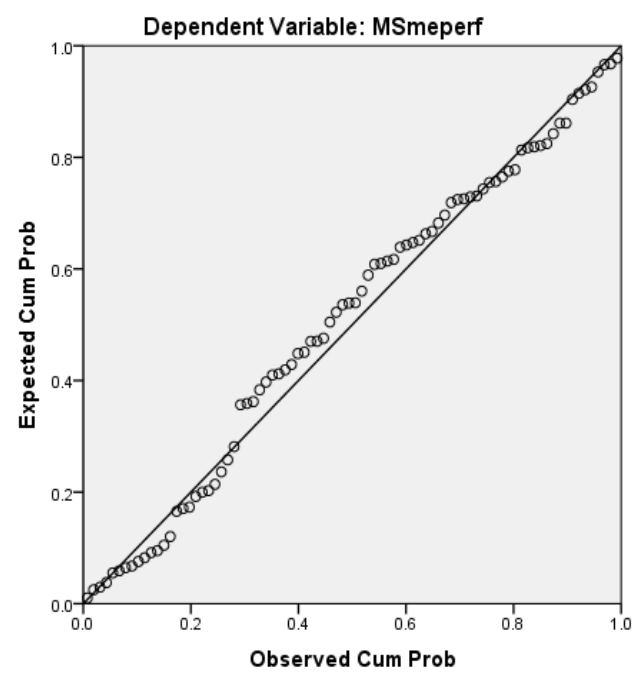

Figure B1. Regression Standardized Residual

\section{Copyrights}

Copyright for this article is retained by the author(s), with first publication rights granted to the journal.

This is an open-access article distributed under the terms and conditions of the Creative Commons Attribution license (http://creativecommons.org/licenses/by/4.0/). 